Торбеевского района) // Российский научный мир. 2014. № 2 (4). С. 91-103.

2. Березуцкий М.А. Антропогенная трансформация флоры // Ботанический журнал. 1999. Т. 84, № 6. C. $8-19$.

3. Сенатор С.А., Тохтарь В.К., Курской А.Ю. Материалы к флоре железных дорог Белгородской области // Вестник Удмуртского университета. Серия «Биология. Науки о Земле». 2016. Т. 26, № 4. С. 50-59.

4. Литвинов Д.И. О южных заносных растениях на северных станциях Мурманской железной дороги // Изв. АН СССР. VI сер. Т. 20. Л., 1926. С. 59-66.

5. Brandes D. Flora und Vegetation der Bahnhöfe Mitteleuropas // Phytocoenologia. 1983. Vol. 11. S. 31115.

6. Борисова Е.А. Инвазии древесных растений в природные сообщества Верхневолжского региона // Российский журнал биологических инвазий. Т.9, № 1. 2016. C. 24-30.

7. Galera H. et al. Encroachment of forest species into operating and abandoned railway areas in north- eastern Poland // Plant Biosystems. 2011. Vol. 145. P. 23-36.

8. Gańko K. Pozatransportowe funkcje terenów kolejowych // Teka Kom. Arch. Urb. Stud. Krajobr. OL PAN, 2005. S. 216-225.

9. Junghans T. Zur Flora der Hauptbahnhöfe von Mannheim und Heidelberg (Baden-Württemberg) // Braunschweiger Geobotanische Arbeiten. T. 9. 2008. S. 9.

10. Третьякова А.С. Роль железнодорожных магистралей в формировании синантропной флоры Среднего Урала // Экология. 2010. № 2. С. 102-107.

11. Dřevojan P. Vedoucí B., Roleček M. Xerotermní flóra a vegetace zářezů železniční trati Veselí nad Moravou-Vrbovce // Masarykova univerzita Přírodovědecká fakulta Ústav botaniky a zoologie. Brno, 2010.

12. Толмачёв А.И. Методы сравнительной флористики и проблемы флорогенеза. Новосибирск: Наука, 1986. $197 \mathrm{c}$.

13. Маевский П.Ф. Флора средней полосы европейской части России. Изд. 10-е. М.: Т-во науч. изданий КМК, 2006. 600 с.

\title{
ECOLOGICAL AND BOTANICAL FEATURES OF THE RAILROADS FLORA OF THE MIDDLE VOLGA REGION
}

(C) 2018

Nikitin Nikolay Alexandrovich, postgraduate student of Chair of Biology, Ecology and Methods of Teaching Samara State University of Social Sciences and Education (Samara, Russian Federation)

Abstract. The paper summarizes the study of ecological characteristics of the Railways flora in the Middle Volga Region. The author comes to the conclusion that in most cases there aren't any significant differences between aboriginal and alien species of the Railways flora, as well as their settlement of functional zones. The most significant differences have been recorded between aboriginal and alien species in the addition of families, which in turn does not have a decisive role in their addition to the flora as a whole. The author thinks that ecological features of the territory of individual growth are more important than biological features of species and families in the formation of the Railways flora. The developed «scale of oppression» allowed to determine characteristics of a particular individual. In the course of the research the dependence between the degree of oppression of plant organisms and the distance to the railroad tracks was established. The author found no significant differences in reactogenicity between the indigenous and alien species at active human impact on the Railways - both groups showed similar trends of oppression.

Keywords: railways flora; environmental conditions; anthropogenic impact; rail transport; inhibition of activity of individuals; taxonomic structure of flora; anthropogenic areas; transformation of flora; alien species; native species.

УДК 581.5; 581.526.5

Статья поступила в редакцию 05.01.2018

\section{АДАПТИВНЫЕ МЕХАНИЗМЫ ПРОРАСТАНИЯ СЕМЯН КСЕРОФИТНЫХ ЗЛАКОВ ВОСТОЧНОГО ЗАБАЙКАЛЬЯ}

(C) 2018

Пляскина Ирина Николаевна, старший лаборант кафедры биологии

Бондаревич Евгений Александрович, кандидат биологических наук, доцент кафедры химии и биохимии Коцюржинская Наталья Николаевна, кандидат биологических наук, доцент, заведующий кафедрой химии и биохимии

Читинская государственная медицинская академия (2. Чита, Российская Федерация)

Борискин Игорь Анатольевич, кандидат биологических наук, директор

Забайкальский аграрный институт - филиал Иркутского государственного аграрного университета имени А.А. Ежевского (г. Чита, Российская Федерация)

Аннотация. В статье представлены результаты изучения механизмов адаптации дикорастущих злаков Восточного Забайкалья на ранних этапах онтогенеза к условиям среды. Определена всхожесть семян трех видов ксерофитных злаков (Agropyron cristatum (L.) Beauv, Stipa krylovii Roshev, Tripogon chinensis (Franch.) Hack.). Отмечены различия в темпах прорастания зерновок этих злаков в зависимости от отношения к дефициту влаги. Более мезофильный вид (A. cristatum) имел самые высокие показатели всхожести. Большой вклад в обеспечение процесса прорастания вносят запасные питательные вещества, в частности белки. С общим количеством белка связана скорость прорастания. Семена, имеющие больше белка, прорастают быстрее, что может быть связано с появлением осмотически активных веществ в результате гидролиза, позволяющих эффективно использовать почвенную влагу. Семена одного вида злака, собранные в различных популяциях, могут от- 
личаться по количеству запасных белков. Соотношение различных фракций запасных белков может характеризовать происхождение вида. Установлено более высокое содержание глютелиновой фракции у семян S. krylovii. Также отмечается более эффективное использование глютелинов у семян A. cristatum, что также может обеспечить интенсивное прорастание. В целом у изученных видов отмечается разница в темпах мобилизации различных фракций запасных белков.

Ключевые слова: ксерофитные злаки; адаптация; семена; прорастание; всхожесть семян; начальные этапы онтогенеза; запасные вещества семян злаков; запасные белки; метод Лоури; динамика растворимых фракций запасных белков; альбумины; глобулины; проламины; глютелины; значение запасных белков для прорастания семян; Забайкальский край.

\section{Введение}

Представители семейства Мятликовые (Роасеае) имеют важное фитоценотическое значение и часто выступают доминантами и содоминантами в равнинных степях на территории Восточного Забайкалья [1]. Злаки в процессе эволюции выработали разнообразные адаптации, которые обеспечивают им приспособление к суровым условиям региона. Незначительное количество зимних и весенних осадков создает крайне неблагоприятные условия для зимовки растений и их развития весной и в начале лета. В связи с этим особый интерес представляют адаптации на ранних этапах онтогенеза. Поскольку семена и проростки в суровом климате Восточного Забайкалья подвергаются действию перепадов температуры и влажности, происходят изменения в составе запасных веществ. Семена большинства растений содержат много питательных веществ, которые откладываются в виде полимерных инертных соединений в клетках запасающих тканей [2; 3]. Эти запасные вещества сохраняются в семенах для обеспечения последующего прорастания. По преобладанию тех или иных запасных веществ различают три типа зрелых семян: крахмалистые, масличные и белковые. В семенах злаков основным запасным веществом является крахмал. Он же является основным углеродным резервом, который почти весь локализован в эндосперме [2; 4]. Разнообразные формы белков принимают участие во всех процессах, происходящих в живых организмах. Белки растений можно разделить на белки собственно протоплазмы и резервные белки $[3 ; 5]$. К первым относятся структурные и каталитические белки органелл, хромосом, рибосом и мембран клетки. Резервные белки обычно состоят из сравнительно небольшого числа компонентов и, как правило, не сбалансированы по незаменимым аминокислотам [6]. Распространенной является классификация белков по растворимости по Т.Б. Осборну [7]. Различают альбумины (водорастворимые), глобулины (растворимые в 5-10\%-м растворе хлорида натрия), проламины (спирторастворимые), глютелины (растворимые в 0,1-0,2\%-м растворе гидроксида натрия) и склеропротеины (нерастворимые белки оболочек и периферических слоев зерна). Наряду с белками в зерне содержится небелковый азот $(0,7-$ $12,9 \%$ от общего азота), включающий свободные аминокислоты (50-60\%), пептиды, нуклеотиды и др. [8].

В процессе созревания семян происходит накопление запасных белков [5]. При этом в семенах двудольных, а также однодольных (за исключением злаковых) растений созревание сопровождается накоплением глобулинов. Злаки, как одна из эволюционно наиболее продвинутых форм растений, в ходе эволюции приобрели уникальную способность: запасать особую группу белков - проламины [4].
Мобилизация запасных отложений является одним из наиболее важных аспектов роста и развития проростка. Все питательные вещества, необходимые для роста растения, на начальных этапах онтогенеза извлекаются из запасных веществ семян. При прорастании образуются ферменты, расщепляющие запасные белки, а образующиеся аминокислоты и пептиды расходуются на синтез необходимых белков. Позднее проростки получают питание только из почвы и воздуха. До перехода к автотрофному питанию проросток нуждается в постоянном притоке азотистых веществ, которые выделяются при гидролизе белкового комплекса. Поэтому изучение белкового состава семян имеет важное значение для развития концепции устойчивости растений. Большинство работ в этой области посвящено сельскохозяйственным растениям [9-12]. Злаки, не относящиеся к этой группе, исследовались меньше [12-14], хотя для дикорастущих видов растений проблема сохранения жизнеспособности семян, их адаптации к меняющимся условиям среды актуальна. Эти особенности позволяют сохраняться видам в составе фитоценозов в условиях значительной конкуренции осваивать новые пространства для жизни.

Цель исследования: изучение содержания и динамики растворимых фракций запасных белков в зерновках и проростках ксерофитных дикорастущих злаков Восточного Забайкалья.

\section{Объекты и методы исследования}

Объектами изучения служили ксерофитные злаки: Agropyron cristatum (L.) Beauv - житняк гребенчатый, Stipa krylovii Roshev - ковыль Крылова, Tripogon chinensis (Franch.) Hack. - трехбородник китайский. По отношению к ресурсам влаги A. cristatum относится к группе мезоксерофитов [15]. У мезоксерофитов по сравнению с ксерофитами снижены значения максимумов транспирации, а обводненность листьев немного выше. S. krylovii и T. chinensis относятся к группе эуксерофитов, отличающейся умеренной или пониженной скоростью транспирации и низким уровнем обводненности листьев. Сбор семян исследуемых злаков проводили в различных популяциях на территории Забайкальского края (Оловяннинский район, пос. Калангуй - площадка 1 , Красночикойский район, окрестности с. Усть-Урлук - площадка 2, Акшинский район, с. Курулга - площадка 3) в 2013 и 2014 гг. Семена хранились в условиях лаборатории, в бумажных пакетах. Перед проращиванием зерновки стерилизовали с поверхности $70 \%$-м этанолом в течение минуты, затем 1\%-м раствором перманганата калия в течение 20 минут и тщательно промывали дистиллированной водой [16]. Семена проращивали в чашках Петри в термостате при температуре $21^{\circ} \mathrm{C}$ в течение 7 суток (увлажнитель - дистиллированная вода). Проводили подсчет 
Пляскина И.Н., Бондаревич Е.А., Коцюржинская Н.Н., Борискин И.А.

проросших семян (в \%). Для проведения эксперимента использовали 3-кратную повторность, в каждой повторности содержалось 50 семян.

Растворимые запасные белки семян выделялись последовательно из навески массой $100 \pm 0,1$ мг в трехкратной повторности, для определения запасных белков в проросших семенах брали целиком и семя, и проросток. Фракционирование по Осборну [3] проводили по общепринятым методикам [17-20] с модификациями под дикорастущие злаки $[14 ; 21]$ и получали экстракты трех протеиновых фракций - альбумины и глобулины, проламины и глютелины объемом 5-7 мл. Для выделения белков семена размалывали в фарфоровых ступках до 70\% выхода муки, навеску муки обезжиривали н-бутанолом. Альбумины и глобулины экстрагировали трижды водным раствором $\mathrm{NaCl}, 0,4$ моль/л. Осадок отмывали от электролита и оставшихся альбуминов и глобулинов дистиллированной водой. Проламины получали трехкратной экстракцией 70\%-м этанолом при комнатной температуре, фракцию глютелиновых белков - трехкратно с 0,1 моль/л уксусной кислотой. Количественно белки определяли фотометрическим методом по методу Lowry (фотометр «Эксперт003», $\lambda=626$ ), с реактивом Фолина-Чокалтеу (стандарт альбумин плазмы крови).

\section{Результаты и их обсуждение}

В ходе серии экспериментов по проращиванию при достаточном уровне увлажненности семена исследуемых злаков показали разную динамику прорастания (рис. 1). Повышенная всхожесть была отмечена у зерновок A. cristatum (94\%), что может быть связано с мезоксерофитной природой этого вида. У типичных ксерофитов (S. krylovii, T. chinensis) в подобных условиях процент проросших семян был ниже $(75-82 \%$ и 52\% соответственно). Видимое про- растание зерновок A. cristatum и $S$. krylovii отмечается на вторые сутки, у T. chinensis только на четвертые. Также было отмечено, что всхожесть семян S. krylovii, собранных с площадки 1, на вторые сутки превышала этот же показатель для проб, собранных на площадке 2 в 5 раз (65\% и 12,5\% соответственно). Возможно, что это обеспечивается более высоким содержанием запасных белков. При определении растворимых фракций протеинов было выяснено, что белковость семян S. krylovii с первой площадки оказалась выше $(81,99$ мг/г сырой массы), чем у собранных со второй площадки (68,7 мг/Г сырой массы) (табл. 1). Запас питательных веществ мог обеспечить более быстрый переход к ростовым процессам и соответственно большую всхожесть. Количество запасных белков в семенах T. chinensis оказалось значительно меньше $(45,01 \mathrm{мг} / \Gamma$ сырой массы), и это также могло сыграть роль в замедлении темпов прорастания семян этого злака, видимое прорастание которых произошло на четвертые сутки. Зерновки S. krylovii отличаются преобладанием глютелиновой фракции в белковом комплексе (38-40\%) по сравнению с A. cristatum и $T$. chinensis, что может свидетельствовать о древности вида (табл. 2).

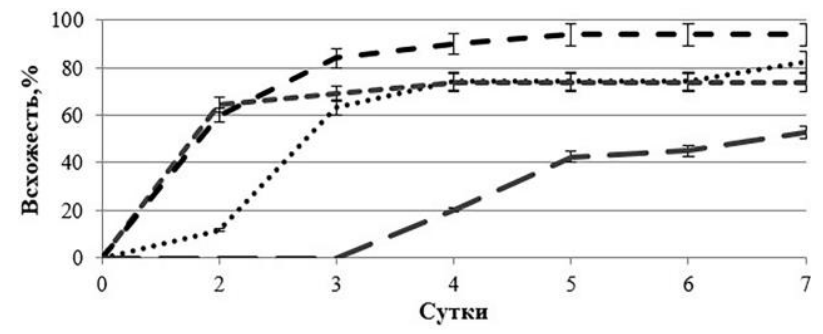

-.... S. krylovii, плошадка 2, 2014 2. - - S. krylovii, плочадка 1, 20142.

- - A. cristatum, площадка 1, 2013 2. - - T. chinensis, площадка 3, 20132.

Рисунок 1 - Динамика прорастания семян, \%

Таблица 1 - Динамика растворимых фракций запасных белков при прорастании семян злаков, мг/г сырой массы

\begin{tabular}{|c|c|c|c|c|}
\hline \multicolumn{5}{|c|}{ S. krylovii, площадка 1, 2014 г. } \\
\hline $\begin{array}{c}\text { Фракция } \\
\text { белков }\end{array}$ & $\begin{array}{c}\text { Альбумины + } \\
\text { Глобулины }\end{array}$ & Проламины & Глютелины & $\begin{array}{c}\sum \text { фракций, } \\
\text { мг/Г сырой массы }\end{array}$ \\
\hline 0 часов & $25,74 \pm 0,44$ & $20,83 \pm 1,41$ & $35,42 \pm 1,15$ & 81,99 \\
\hline 24 часа & $3,45 \pm 0,42$ & $2,56 \pm 0,11$ & $4,80 \pm 0,21$ & 10,85 \\
\hline 48 часов & $10,17 \pm 0,97$ & $5,07 \pm 0,04$ & $12,02 \pm 0,14$ & 27,30 \\
\hline 72 часа & $14,25 \pm 1,19$ & $11,04 \pm 0,54$ & $33,67 \pm 0,37$ & 58,96 \\
\hline 7-е сутки & $10,26 \pm 1,01$ & $13,75 \pm 0,91$ & $22,24 \pm 1,07$ & 46,24 \\
\hline \multicolumn{5}{|c|}{ S. krylovii, площадка 2, 2014 г. } \\
\hline 0 часов & $23,40 \pm 1,80$ & $18,60 \pm 1,60$ & $26,70 \pm 1,50$ & 68,70 \\
\hline 24 часа & $1,64 \pm 0,04$ & $2,64 \pm 0,28$ & $5,45 \pm 1,24$ & 9,69 \\
\hline 48 часов & $8,49 \pm 0,05$ & $5,15 \pm 0,08$ & $19,66 \pm 1,04$ & 33,40 \\
\hline 72 часа & $9,99 \pm 0,13$ & $7,39 \pm 0,05$ & $20,01 \pm 0,79$ & 37,40 \\
\hline 7-е сутки & $26,03 \pm 0,04$ & $15,83 \pm 2,11$ & $25,09 \pm 2,43$ & 66,95 \\
\hline \multicolumn{5}{|c|}{ A. cristatum, площадка 1, 2013 г. } \\
\hline 0 часов & $37,0 \pm 0,05$ & $15,0 \pm 1,02$ & $20,0 \pm 1,54$ & 72,0 \\
\hline 24 часа & $10,44 \pm 1,60$ & $6,12 \pm 0,84$ & $6,1752 \pm 0,07$ & 22,72 \\
\hline 48 часов & $11,94 \pm 1,64$ & $4,39 \pm 0,37$ & $1,27 \pm 0,07$ & 17,70 \\
\hline 72 часа & $17,34 \pm 1,85$ & $12,38 \pm 0,24$ & $14,07 \pm 1,83$ & 43,80 \\
\hline 7-е сутки & $17,68 \pm 1,05$ & $11,38 \pm 1,02$ & $16,26 \pm 1,20$ & 45,32 \\
\hline \multicolumn{5}{|c|}{ T. chinensis, площадка 3, 2013 г. } \\
\hline 0 часов & $20,0 \pm 0,99$ & $17,01 \pm 0,15$ & $8,0 \pm 0,35$ & 45,01 \\
\hline 24 часа & $17,32 \pm 0,90$ & $9,49 \pm 1,71$ & $7,56 \pm 1,26$ & 34,37 \\
\hline 48 часов & $11,14 \pm 0,46$ & $8,56 \pm 0,98$ & $6,45 \pm 0,35$ & 26,15 \\
\hline 72 часа & $10,56 \pm 0,59$ & $7,09 \pm 0,41$ & $5,80 \pm 0,37$ & 23,45 \\
\hline 7-е сутки & $9,02 \pm 1,11$ & $7,07 \pm 0,33$ & $5,78 \pm 1,36$ & 21,87 \\
\hline
\end{tabular}


Пляскина И.Н., Бондаревич Е.А., Коцюржинская Н.Н., Борискин И.А.

Адаптивные механизмы прорастания семян ксерофитных злаков Восточного Забайкалья

03.02.00 - общая биология

Таблица 2 - Динамика растворимых фракций запасных белков при прорастании семян злаков, \%

\begin{tabular}{|c|c|c|c|c|c|c|c|c|c|c|c|c|}
\hline & \multicolumn{3}{|c|}{ S. krylovii, площадка 1} & \multicolumn{3}{|c|}{ S. krylovii, площадка 2} & \multicolumn{3}{|c|}{ A. cristatum, площадка 1} & \multicolumn{3}{|c|}{ T. chinensis, площадка 3} \\
\hline & $\mathrm{A}+\Gamma$ & Пр. & Гл. & $A+\Gamma$ & Пр. & Гл. & $A+\Gamma$ & Пр. & Гл. & $A+\Gamma$ & Пр. & Гл. \\
\hline 0 ч. & 31,4 & 25,4 & 43,2 & 34,06 & 27,1 & 38,9 & 51,4 & 20,8 & 27,8 & 44,4 & 37,8 & 17,8 \\
\hline 24 ч. & 32 & 24 & 44 & 16,9 & 27 & 56 & 45,7 & 27 & 27,3 & 50,4 & 27,6 & 22 \\
\hline 48 ч. & 37,4 & 18,6 & 44 & 25 & 15,4 & 59 & 67,8 & 25 & 7 & 42,6 & 33 & 25 \\
\hline 72 ч. & 24 & 18,7 & 57 & 26,7 & 19,8 & 53,5 & 39,2 & 28,6 & 32,3 & 45 & 30 & 25 \\
\hline 120 ч. & 31 & 24 & 45 & 29 & 22,6 & 48 & 21 & 12,4 & 13,5 & 41,2 & 32,3 & 26,5 \\
\hline 168 ч. & 22,3 & 29,6 & 48 & 39 & 23,6 & 37,5 & 39 & 25 & 36 & 41,2 & 32,3 & 26,5 \\
\hline
\end{tabular}

Примечание. $A+\Gamma$ - альбуминовая и глобулиновая фракция, Пр. - проламины, Гл. - глютелины.

Несмотря на то, что семена S. krylovii были собраны в разных популяциях, значительно удаленных друг от друга, соотношение растворимых фракций запасных белков в них оказалось примерно равным. В них преобладают глютелины (38-40\%), несколько меньше содержание альбуминов и глобулинов (31$34 \%)$, а количество проламиновой фракции было меньшим (25\%). У зерновок A. cristatum и T. chinensis в белковом комплексе преобладают водо- и солерастворимые фракции (табл. 2). Доля проламинов у изученных злаков имеет большее значение у семян $T$. chinensis и составляет $38 \%$ от суммы всех фракций.

В первые сутки после увлажнения семян у S. krylovii повышается доля глютелиновой фракции, идет незначительное уменьшение альбуминов и глобулинов, доля проламинов практически не изменялась. У A. cristatum уменьшилась доля альбуминов и глобулинов. То есть у видов, которые имели большую всхожесть и более быстрые темпы прорастания (S. krylovii, A. cristatum), в первые сутки происходит мобилизация альбуминов и глобулинов. В то время как вид с замедленным прорастанием (T. chinensis) в первые сутки использует проламиновую фракцию запасных белков.

На вторые сутки у S. krylovii, A. cristatum наступает так называемое видимое прорастание, которое характеризуется тем, что часть зародыша, как правило зародышевый корень, растягивается и проникает в окружающие зародыш структуры. В это время уменьшилось количество проламинов (табл. 2), у S. krylovii уменьшение более сильное, у A. cristatum незначительное. Как известно, эта фракция белков легче мобилизуется и на этом этапе может обеспечить ростовые процессы субстратами. Различия выявлены в использовании этими видами глютелинов. В семенах A. cristatum сильно уменьшается доля этой фракции белков (до 7\%), a S. krylovii на этом этапе прорастания медленно использует эту фракцию. У A. cristatum в это время значительно повышается доля альбуминов и глобулинов (68\%). В эту фракцию входят белки, обладающие ферментативной активностью, которые могут способствовать мобилизации глютелинов и наряду с этим участвовать в синтетических процессах, обеспечивающих прорастание. У T. chinensis в это время уменьшается доля альбуминов и глобулинов, но соотношение фракций в целом остается постоянным. К концу периода наблюдения за прорастанием (7 сутки) у всех исследованных злаков происходило уменьшение общего количества 100 растворимых фракций белков (табл. 1). У семян S. krylovii с первой площадки уменьшилось количество альбуминов, глобулинов и глютелинов и незначительно возросло количество проламинов. В совокупности это привело к уменьшению общего количества экстрагируемого белка. Зерновки этого вида со второй площадки характеризуются значительным увеличением доли альбуминов, глобулинов и проламинов (почти в 2 раза) в период от третьих до седьмых суток, тогда как доля глютелинов изменяется незначительно. В результате отмечается 2-кратное увеличение суммы растворимых фракций. У A. cristatum и T. chinensis к седьмым суткам прорастания отмечается стабилизация концентрации каждой из фракций и общего количества этих белков. Вероятно, переход от гетеротрофного питания к автотрофному активирует ферментные комплексы, гидролизующие прочные связи в трудноэкстрагируемых фракциях.

\section{Заключение}

Семена изучаемых злаков отличаются соотношением растворимых фракций запасных белков и общим количеством запасных белков. Увеличение количества белка в зерновках может обеспечить интенсивный темп набухания и более быстрое прорастание. Начинающийся гидролиз запасных белков ведет к образованию осмотически активных веществ, что формирует градиент концентрации влаги, обеспечивающий интенсивность поступления воды в ткани из субстрата. Это позволяет зерновкам быстрее перейти к прорастанию даже в условиях дефицита влаги за короткий промежуток времени. Различия в количественном соотношении и разных стратегиях использования фракций белков семенами и проростками могут свидетельствовать о видовых особенностях. У вида, выдерживающего наиболее экстремальные условия увлажнения (T. chinensis), расход проламинов имел тенденцию к уменьшению, тогда как у других злаков интенсивнее расходовались альбумины и глобулины. Таким образом, проламины имеют существенное значение для метаболизма проростков и могут обеспечивать прорастание и рост ксерофитных злаков в условиях дефицита влаги.

\section{Список литературы:}

1. Дулепова Б.И. Степи горной лесостепи Даурии. Иркутск: Мин. прос. РСФСР, 1986. 86 с.

2. Соболев А.М., Жданова Л.П. Отложение веществ в запас // Физиология семян. М.: Изд-во «Наука», 1982. С. 48-101. 
Пляскина И.Н., Бондаревич Е.А., Коцюржинская Н.Н., Борискин И.А.

3. Хелдт Г.-В. Биохимия растений. М.: БИНОМ, 2011. С. 283-288.

4. Соболев А.М. Запасание белка в семенах растений. М.: Изд-во «Наука», 1985. 112 с.

5. Растительные белки и их биосинтез / сост. В.Л. Кретович. М.: Изд-во «Наука»,1975. 342 с.

6. Семихов В.Ф. Концепция аминокислотного состава гипотетического предка злаков (Роасеае) и ее использование для целей систематики этого семейства // Бот. журнал. 1988. Т. 73, № 9. С. 1225-1234.

7. Осборн Т.Б. Растительные белки. М., Л.: Биомедгиз, 1935. 220 с.

8. Shewry P.R., Halford N.G. Cereal seed storage proteins: structures, properties and role in grain utilization // Journal of Experimental Botany. 2002. Vol. 53, № 370. P. 947-958.

9. Kries M., Forde B.G., Rahman S., Miflin B.J., Shewry P.R. Molecular evolution of the seed storage proteins of barley, rye and wheat // Journal of Molecular Biology. 1985. Vol. 183 (3). P. 499-502.

10. Верхотуров В.В. Физиолого-биохимические процессы в зерновках ячменя и пшеницы при их хранении, прорастании и переработке: автореф. дис. ... канд. биол. наук. М., 2008. 40 с.

11. Осипова С.В. Ферментативная регуляция $\mathrm{SS} / \mathrm{SH}$ редокс статуса запасных белков и качества клейковины пшеницы: автореф. дис. ... д-ра биол. наук. Иркутск, 2011. 40 с.

12. Семихов В.Ф., Тимощенко А.С., Арефьева Л.П. Адаптивный потенциал злаков в интродукции растений. Пущино: ОНТИПНЦРАН, 2006. 49 с.

13. Илли И.Э., Якимова Е.П. Мобилизация запасных веществ при прорастании зерновок ксерофитных злаков Восточного Забайкалья // Ученые записки Забайкальского государственного университета. Сер.: Естественные науки. 2009. № 1. С. 68-78.

14. Бондаревич Е.А., Борискин И.А., Якимова Е.П. Эколого-биологические особенности злаков Восточного Забайкалья. Чита: Экспресс-издательство, 2013. $184 \mathrm{c}$.

15. Касьянова Л.Н. Экология растений Прибайкалья (водный обмен). М.: Наука, 2004. С. 192-193.

16. Дмитричева Д.С., Яппаров А.Х., Дегтярева И.А. Ризосферные аборигенные микроорганизмы, способствующие росту и развитию растений // Ученые записки Казанской государственной академии. 2011. T. 207. С. $186-190$.

17. Конарев В.Г. Проблема пищевой ценности растительных белков. Растительные белки и их биосинтез. М.: Наука, 1975. С. 5-20.

18. Труфанов В.А. Клейковина пшеницы: проблемы качества. Новосибирск: Наука, 1994. 166 с.

19. Биссвагнер Х. Практическая энзимология. М.: БИНОМ. Лаборатория знаний, 2011. С. 182-183.

20. Мошков И.Е., Степанченко Н.С., Новикова Г.В. Количественное определение содержания белка. Молекулярно-генетические и биохимические методы в современной биологии растений. М.: БИНОМ, Лаборатория знаний, 2012. С. 201-212.

21. Бондаревич Е.А., Осипова С.В. Высокое содержание глютелинов в семенах реликтового злака Melica turchaninowiana (Poaceae) // Журнал Сибирского федерального университета. Биология. 2010. T. 4, № 3. C. 384-390.

\section{ADAPTIVE MECHANISMS \\ OF XEROPHYTIC CEREALS SEEDS GERMINATION IN EASTERN TRANSBAIKALIA}

(C) 2018

Plyaskina Irina Nikolaevna, laboratory assistant of Biology Department

Bondarevich Evgeniy Aleksandrovich, candidate of biological sciences,

associate professor of General Chemistry and Biochemistry Department

Kotsyurzhinskaya Natalia Nikolaevna, candidate of biological sciences, associate professor, head of General Chemistry and Biochemistry Department

Chita State Medical Academy (Chita, Russian Federation)

Boriskin Igor Anatolyevich, candidate of biological sciences, director

Zabaykalsky Agrarian Institute - branch of Irkutsk State Agricultural University named after A.A. Ezhevsky (Chita, Russian Federation)

Abstract. The paper deals with the study of adaptation mechanisms of Eastern Transbaikalia wild cereals to environmental conditions at the initial ontogenesis stages. The authors have determined the germination of three species xerophytic cereals seeds (Agropyron cristatum (L.) Beauv, Stipa krylovii Roshev, Tripogon chinensis (Franch.) Hack.). The authors have noted differences in rates of seed germination of these cereals depending on the relation to moisture deficiency. More mesophilic species (A. cristatum) had the highest rates of germination. A large contribution to the process of germination is made by storage nutrients, proteins in particular. The total amount of protein is related to the rate of germination. Seeds with more protein sprout faster, which may be due to the appearance of osmotically active substances as a result of hydrolysis, which makes it possible to effectively use soil moisture. Seeds of one type of cereal collected in different populations may differ in the content of storage proteins. The ratio of different fractions of storage proteins can characterize the origin of the species. A higher content of glutelin fraction was found in the seeds of S. krylovii. There is also a more effective use of glutelins in the seeds of A. cristatum, which can also provide intensive germination. In general, the studied species have a difference in the rates of mobilization of various fractions of storage proteins.

Keywords: xerophytic cereals; adaptation; seeds; germination; seed germination; initial stages of ontogenesis; storage substances of cereals seeds; storage proteins; Lowry method; dynamics of soluble fractions of storage proteins; albumins; globulins; prolamins; glutelins; importance of storage proteins for germination of seeds; Zabaykalsky Krai. 